Удк 336.1

JEL classification: E62, G28, H29, H39, 011.

DOI: https://doi.org/10.35774/visnyk2019.03.051

\title{
Валентина МАРТИНЕНКО,
}

кандидат економічних наук, доцент,

заступник директора навчально-наукового інституту обліку, аналізу та аудиту,

Університет державної фіскальної служби України,

вул. Університетська, б. 31, м. Ірпінь, Київська обл., 08201, Україна.

E-mail: martynenkovv86@gmail.com

ORCID: https://orcid.org/0000-0001-9078-8345.

\section{СПЕЦИФІКА УПРАВЛІННЯ ВЛАСНИМИ ДОХОДАМИ МІСЦЕВИХ БЮДЖЕТІВ В УМОВАХ ФІНАНСОВОЇ ДЕЦЕНТРАЛІЗАЦІЇ}

Мартиненко В. Специфріка управління власними доходами місцевих бюджетів в умовах фрінансової децентралізації. Вісник Тернопільського національного економічного університету. 2019. Вип. 3. C. 51 - 61. DOI: https://doi.org/10.35774/ visnyk2019.03.051

Martynenko, V. (2019). Spetsyfika upravlinnia vlasnymy dokhodamy mistsevykh biudzetiv $v$ umovakh finansovoi detsentralizatsii [Specificity of managing local budgets' own revenues in the context of financial decentralization]. The Herald of Ternopil National Economic University, Vol. 3. P. 51 - 61. DOI: https://doi.org/10.35774/visnyk2019.03.051

\section{Анотація}

Вступ. В Україні, починаючи з 2014 р., реалізується реформа децентралізації, мета якої полягає у передачі частини владних повноважень центральних органів державної влади громадам. Оскільки у фрінансовій сфрері реформа децентралізації передбачає забезпечення фонансової автономії територіально-адміністративних одиниць, аналіз основних чинників впливу на управління власними доходами місцевих бюджетів набуває особливої актуальності.

Mета - дослідити специфріку та особливості управління власними доходами місцевих бюджетів України в умовах фрінансової децентралізації.

Mетоди. Основні методи дослідження, використані у статmі: порівняльний аналіз-для ранжування власнихнадходжень зведених обласних бюджетів за обсягом; фракторний аналіз - для ідентифікації та відбору фракторів впливу на фрормування власних доходів місцевих бюджетів; регресійний аналіз - для фрормалізації впливу визначених фракторів на динаміку власних доходів зведених обласних бюджетів.

(C) Валентина Мартиненко, 2019. 
Результати. Обгрунтовано, що основу фрінансової автономії громади в умовах фінансової децентралізації забезпечують широкі повноваження щодо управління формуванням власних надходжень до ї̈ бюджету. Встановлено, що у 2017 p. порівняно з 2014 р. власні доходи місцевих бюджетів України збільшилися в 2,3 рази, у тому числі як результат фрінансової децентралізації. Доведено, що, проводячи децентралізацію управління власними доходами місцевих бюджетів, центральні органи державної влади, розширюючи фрінансові повноваження адміністративнотериторіальних одиниць, мають забезпечити зростання добробуту громадян, справедливість у реаіональному розподілі доходів населення, сповільнення трудової імміграції.

Висновки. Одержані результати дозволяють сформувати базу для розробки основних сценаріїв прогнозу фрінансової автономії місцевих бюджетів України в їх регіональному розрізі, чому будуть присвячені подальші наукові дослідження автора.

Ключові слова: власні доходи, місцеві бюджети, органи місцевої влади, територіально-адміністративна одиниця, фріскальна політика, фрінансова децентралізація, формалізація.

Формули: 2, рис.: 2, табл.: 3, бібл.: 12.

\section{Abstract \\ Valentyna MARTYNENKO \\ SPECIFICITY OF MANAGING LOCAL BUDGETS' OWN REVENUES IN THE CONTEXT OF FINANCIAL DECENTRALIZATION}

Introduction. Decentralization reform in Ukraine has been implemented since 2014. It aims at transferring some of the powers of central government to the communities. The reform of decentralization in the financial sphere should ensure the financial autonomy of territorial-administrative units. Therefore, the analysis of the main factors influencing the management of own revenues of local budgets is especially relevant.

Research purpose is to investigate the specifics and features of managing the own revenues of local budgets of Ukraine under conditions of financial decentralization.

Methods. Several research methods are used in the article. These are: comparative analysis - to rank own revenues of consolidated regional budgets by volume; factor analysis - to identify and select factors of influence on the formation of own revenues of local budgets; regression analysis - to formalize the influence of certain factors on the dynamics of own revenues of consolidated regional budgets.

Results. It is proved that the basis of the community's financial autonomy in the context of financial decentralization is provided by broad powers to manage the formation of its own revenues to its budget. It was established that in 2017 compared with 2014, own revenues of local budgets of Ukraine increased by 2.3 times, including as a result of financial decentralization. It is proved that, by decentralizing the management of own revenues of local budgets, central government bodies, expanding the financial powers of administrative-territorial units, should ensure the growth of citizens' well-being, fairness in the regional distribution of incomes, and slowdown of labor immigration. 
Conclusions. The obtained results make it possible to form the basis for the development of the main scenarios of forecasting the financial autonomy of the local budgets of Ukraine in their regional context. Further scientific researches of the author will be devoted to it.

Key words: own income, local budgets, local authorities, territorial-administrative unit, fiscal policy, financial decentralization, formalization.

Formulas: 2, fig.: 2, tabl.: 3, bibl.: 12.

Постановка проблеми. Власні доходи місцевого бюджету - це всі податкові і неподаткові надходження, акумульовані органом місцевої влади за рік, за виключенням міжбюджетних трансфертів. Їх роль важлива з огляду на забезпечення фінансової автономії адміністративно-територіальних одиниць в умовах реформи децентралізації владних повноважень, що реалізується в Україні з 2014 р. Саме фрінансову автономію адміністративно-територіальних одиниць можна вважати головною метою фріскальної політики в умовах фрінансової децентралізації. У зв'язку з цим виявлення специфіки управління власними доходами місцевих бюджетів при модернізації фіскальної політики в умовах фрінансової децентралізації $€$ актуальним і потребує ґрунтовного дослідження.

Аналіз останніх досліджень і публікацій. Базовим теоретико-методологічним засадам та прикладним аспектам фрінансової децентралізації присвячено праці таких зарубіжних і вітчизняних учених-економістів, як А. Киріаку, Л. Муїнело-Галло та О. РокаСагалес (2013) [1], І. Волохова (2014) [2], І. Сидор (2014) [3], Х. Мартинес, Т. Баскаран, Л. Фельд і Я. Шнелленбах (2016) [4], Г. Возняк (2019) [5] та ін. Проте управління власними доходами місцевих бюджетів при модернізації фіскальної політики в умовах фрінансової децентралізації залишається маловивченою проблемою, вирішенню якої, розпочатому автором у працях [6-8], присвячене це дослідження.

Метою статті $€$ дослідження специфріки та особливостей управління власними доходами місцевих бюджетів України в умовах фрінансової децентралізації.

Виклад основного матеріалу дослідження. Серед власних доходів місцевих бюджетів в Україні виокремлюють податкові та неподаткові надходження. Згідно з Бюджетним кодексом України, до складу власних податкових доходів місцевих бюджетів у період реалізації реформи децентралізації входять, крім місцевих податків і зборів (встановлених сільськими, селищними, міськими радами та радами об'єднаних територіальних громад у межах своїх повноважень згідно з Податковим кодексом [9]), 60\% податку на доходи фрізичних осіб (15\% осідає в обласних бюджетах), $25 \%$ екологічного податку, 10\% податку на прибуток підприємств (крім комунальної власності), частини чотирьох видів рентної плати за користування надрами. Власними неподатковими доходами місцевих бюджетів $є$ надходження від бюджетних установ, доходи від власності та підприємницької діяльності (окрім НБУ), адміністративні збори та платежі та ін. [10].

Для оцінки специфіки управління власними доходами місцевих бюджетів в умовах реалізації реформи фінансової децентралізації, яку розпочато з 2014 р., проведемо спочатку аналіз динаміки власних доходів місцевих бюджетів (без урахування офріційних трансфертів) в розрізі зведених обласних бюджетів України за 20142017 рр. (табл. 1). 
Власні доходи місцевих бюджетів (без урахування офріційних трансфертів) в розрізі зведених обласних бюджетів України, млн. грн.

\begin{tabular}{|c|c|c|c|c|c|c|}
\hline \multirow{2}{*}{ Назва області / обласний центр } & \multicolumn{4}{|c|}{ Значення показника за роками } & \multirow{2}{*}{$\begin{array}{l}2017 \text { р. у \% } \\
\text { до } 2014 \text { р. }\end{array}$} & \multirow{2}{*}{$\begin{array}{c}\text { Середнє за } \\
\text { 2014-2017 pp }\end{array}$} \\
\hline & 2014 & 2015 & 2016 & 2017 & & \\
\hline Вінницька / Вінниця & 3111,3 & 3790,5 & 5651,4 & 8225,0 & 264,4 & 5194,6 \\
\hline Волинська / Луцьк & 1590,3 & 2209,0 & 3092,3 & 4726,1 & 297,2 & 2904,4 \\
\hline Дніпропетровська / Дніпро & 11030,3 & 13203,4 & 17944,7 & 23266,4 & 210,9 & 16361,2 \\
\hline Донецька / Донецьк & 9651,9 & 7093,2 & 8764,6 & 11944,9 & 123,8 & 9363,7 \\
\hline Житомирська / Житомир & 2358,5 & 2765,2 & 4021,7 & 5695,8 & 241,5 & 3710,3 \\
\hline Закарпатська / Ужгород & 1580,1 & 2071,1 & 3106,9 & 4608,8 & 291,7 & 2841,7 \\
\hline Запорізька / Запоріжжя & 4652,4 & 5602,2 & 8678,0 & 10879,0 & 233,8 & 7452,9 \\
\hline Івано-Франківська / Івано-Франківськ & 2028,8 & 2571,2 & 3662,6 & 5071,1 & 250,0 & 3333,4 \\
\hline Київська / Київ & 4833,6 & 6141,9 & 9224,0 & 13762,5 & 284,7 & 8490,5 \\
\hline Кіровоградська / Кропивницький & 2042,2 & 2419,0 & 3564,1 & 4902,6 & 240,1 & 3232,0 \\
\hline Луганська / Луганськ & 3306,1 & 2163,6 & 2479,1 & 3163,4 & 95,7 & 2778,1 \\
\hline Львівська / Львів & 4840,2 & 6415,5 & 9956,4 & 13310,0 & 275,0 & 8630,5 \\
\hline Миколаївська / Миколаїв & 2415,4 & 2943,0 & 4338,9 & 5812,1 & 240,6 & 3877,4 \\
\hline Одеська / Одеса & 5607,5 & 6940,5 & 10763,3 & 15998,7 & 285,3 & 9827,5 \\
\hline Полтавська / Полтава & 3911,4 & 4822,9 & 6931,4 & 9359,9 & 239,3 & 6256,4 \\
\hline Рівненська / Рівне & 1876,4 & 2208,4 & 3122,5 & 4621,0 & 246,3 & 2957,1 \\
\hline Сумська / Суми & 2290,1 & 2718,5 & 3998,9 & 5664,0 & 247,3 & 3667,9 \\
\hline Тернопільська / Тернопіль & 1403,4 & 1860,9 & 2571,6 & 3623,3 & 258,2 & 2364,8 \\
\hline Харківська / Харків & 6568,0 & 7872,4 & 11305,6 & 15070,0 & 229,4 & 10204,0 \\
\hline Херсонська / Херсон & 1827,4 & 2273,1 & 3299,8 & 4502,1 & 246,4 & 2975,6 \\
\hline Хмельницька / Хмельницький & 2334,9 & 2933,7 & 4169,8 & 5822,2 & 249,4 & 3815,2 \\
\hline Черкаська / Черкаси & 2582,2 & 3193,4 & 4650,6 & 6329,5 & 245,1 & 4188,9 \\
\hline Чернівецька / Чернівці & 1244,8 & 1656,0 & 2529,9 & 3116,5 & 250,4 & 2136,8 \\
\hline Чернігівська / Чернігів & 1992,0 & 2433,6 & 3651,3 & 5016,6 & 251,8 & 3273,4 \\
\hline місто Київ & 14821,3 & 22178,2 & 29268,2 & 35004,0 & 236,2 & 25317,9 \\
\hline Всього власних доходів & 101914,5 & 122495,4 & 172763,6 & 231512,5 & 227,2 & 6206,2 \\
\hline
\end{tabular}

Джерело: розроблено та проведено розрахунки за даними Державної казначейської служби України [11] без урахування тимчасово окупованої території Автономної Республіки Крим (АРК), м. Севастополя та частини тимчасово окупованих територій у Донецькій та Луганській областях.

3 даних, наведених у табл. 1, видно, що сукупний обсяг власних доходів зведених обласних бюджетів України упродовж 2014-2017 рр. збільшився у 2,3 рази. При цьому найбільший приріст власних доходів характерний для прикордонних областей: Волинської (+197,2\%), Закарпатської (+191,7\%) та Одеської (+185,3\%). Найменший приріст характерний для областей, частина території яких перебуває в тимчасовій окупації: -4,3\% для Луганської області та +23,8\% для Донецької. Лідерами за обсягами власних доходів виявилися зведені обласні бюджети Одещини (16 млрд. грн., або 7\% власних доходів місцевих бюджетів у 2017 р.), Дніпропетровщини (23,3 млрд. грн., або 10,1\% власних доходів місцевих бюджетів у 2017 р.) і бюджет столиці (35 млрд. грн., або 15,3\% власних доходів місцевих бюджетів у 2017 р.). Аутсайдерами за збором власних фрінансових ресурсів у 2017 р. були Тернопільська область (3,6 млрд. грн., або 1,6\% власних доходів місцевих бюджетів), Луганська область (3,2 млрд. грн., або $1,4 \%$ власних доходів місцевих бюджетів) та Чернівецька область (3,1 млрд. грн., або 1,4\% власних доходів місцевих бюджетів).

Зрозуміло, що найбільший вплив на дохідну частину місцевих бюджетів мають доходи фрізичних осіб, оскільки в розрізі власних доходів місцевих бюджетів їх питома 
вага найбільша (наприклад, 48\% за станом на кінець 2017 р.). Тому й фрлагманами із формування власних фрінансових ресурсів стали регіони України з найбільшим обсягом доходів населення - місто Київ лідер у 2017 р., Дніпропетровська область була другою, Одеська область - четвертою (табл. 2).

Таблиця 2

\section{Доходи населення України в регіональному розрізі впродовж 2014-2017 рр., млн. грн.}

\begin{tabular}{|l|c|c|c|c|c|}
\hline \multirow{2}{*}{ Область / обласний центр } & \multicolumn{3}{|c|}{ Значення показника за роками } & \multirow{2}{*}{ Cереднє за } \\
\cline { 2 - 5 } & 2014 & 2015 & 2016 & 2017 & 2017 рр. \\
\hline Вінницька / Вінниця & 49418 & 60923 & 71888 & 94417 & 69162 \\
\hline Волинська / Луцьк & 27986 & 34064 & 40792 & 53204 & 39012 \\
\hline Дніпропетровська / Дніпро & 136810 & 166076 & 188816 & 245778 & 184370 \\
\hline Донецька / Донецьк & 142745 & 117471 & 117735 & 141340 & 129823 \\
\hline Житомирська / Житомир & 36814 & 45053 & 53684 & 70126 & 51419 \\
\hline Закарпатська / Ужгород & 29988 & 37182 & 44137 & 56568 & 41969 \\
\hline Запорізька / Запоріжжя & 68327 & 81737 & 96695 & 122759 & 92380 \\
\hline Івано-Франківська / Івано-Франківськ & 37848 & 47152 & 56418 & 73474 & 53723 \\
\hline Київська / Київ & 63342 & 76150 & 90505 & 117755 & 86938 \\
\hline Кіровоградська / Кропивницький & 28901 & 35350 & 41875 & 54514 & 40160 \\
\hline Луганська / Луганськ & 56233 & 44157 & 41267 & 49342 & 47750 \\
\hline Львівська / Львів & 79378 & 97740 & 116285 & 152256 & 111415 \\
\hline Миколаївська / Миколаїв & 36373 & 44275 & 52390 & 67558 & 50149 \\
\hline Одеська / Одеса & 80438 & 101179 & 118472 & 153640 & 113432 \\
\hline Полтавська / Полтава & 49928 & 60610 & 71926 & 92768 & 68808 \\
\hline Рівненська / Рівне & 33314 & 40309 & 47356 & 61831 & 45703 \\
\hline Сумська / Суми & 35375 & 44311 & 52551 & 67287 & 49881 \\
\hline Тернопільська / Тернопіль & 26892 & 33851 & 40277 & 52196 & 38304 \\
\hline Харківська / Харків & 95897 & 116880 & 135675 & 175850 & 131076 \\
\hline Херсонська / Херсон & 30077 & 38233 & 44268 & 57144 & 42431 \\
\hline Хмельницька / Хмельницький & 38853 & 48653 & 57367 & 73520 & 54598 \\
\hline Черкаська / Черкаси & 36694 & 44708 & 53496 & 69399 & 51074 \\
\hline Чернівецька / Чернівці & 22941 & 28316 & 33657 & 43542 & 32114 \\
\hline Чернігівська / Чернігів & 31998 & 38780 & 45716 & 58255 & 43687 \\
\hline місто Київ & 240198 & 288856 & 338083 & 447559 & 328674 \\
\hline
\end{tabular}

Джерело: розроблено та проведено розрахунки за даними Державної служби статистики України [12] без урахування тимчасово окупованої території АРК, м. Севастополя та частини тимчасово окупованих територій у Донецькій та Луганській областях.

Згідно з усередненими даними за 2014-2017 рр., наведеними у табл. 2, найбільш багатим регіоном України є столиця з 328,7 млрд. грн., наступною стала Дніпропетровська область 3 184,4 млрд. грн., замикає трійку лідерів Харківська область з 131,1 млрд. грн. Найбіднішими стали Волинська (39 млрд. грн.), Тернопільська (38,3 млрд. грн.) і Чернівецька (32,1 млрд. грн.) області. На місто Київ і 5 областей (24\%), середні доходи населення яких за 2014-2017 рр. переважають 100 млрд. грн., припадає половина всіх доходів населення України. Аналізуючи регіональну динаміку доходів, слід відзначити, що найбільший приріст у 2017 р. порівняно 3 2014 р.демонструють Львівська $(+91,8 \%)$, Івано-Франківська $(+94,1 \%)$ і Тернопільська $(+94,1 \%)$ області. Одночасно зменшилися доходи населення в Донецькій області на $1 \%$ і в Луганській області на 12,3\% через тимчасову окупацію частини їх територій і активні військові дії. 
Проведемо оцінку впливу доходів населення області на власні доходи зведених обласних бюджетів. Для цього по осі абсцис відкладемо середні значення доходів населення областей України та міста Києва за 2014-2017 рр., а по осі ординат середні обсяги власних доходів зведених обласних бюджетів України. В результаті одержуємо графік, що формалізує вплив середньорічних доходів населення областей на середньорічний обсяг власних доходів зведених обласних бюджетів України за 2014-2017 рр. (рис. 1).

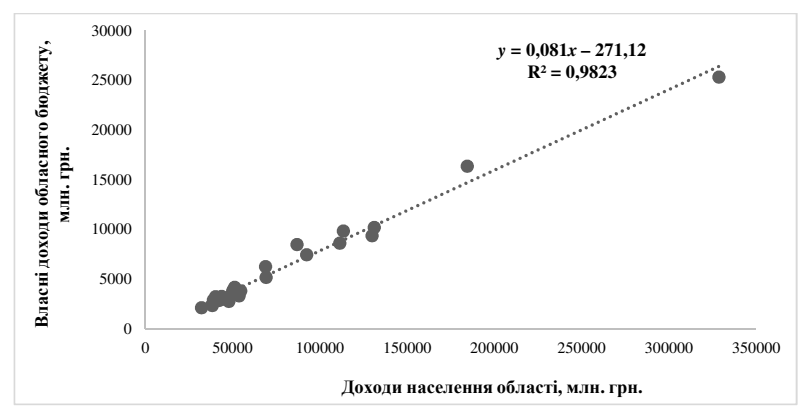

Рис. 1. Формалізація впливу середньорічних доходів населення областей на середньорічний обсяг власних доходів зведених обласних бюджетів України за 2014-2017 рр.

Джерело: розроблено та проведено розрахунки за даними Державної казначейської служби України [11] та Державної служби статистики України [12] без урахування тимчасово окупованої території АРК, м. Севастополя та частини тимчасово окупованих територій у Донецькій та Луганській областях.

3 формули, наведеній на рис. 1, можна зробити висновок, що при зростанні доходів населення області на 1 млн. грн. власні доходи зведеного обласного бюджету можуть збільшитися на 81 тис. грн. При цьому коефіцієнт парної детермінації $R^{2}=0,982$ означає, що зростання власних доходів зведених обласних бюджетів на 98,2\% обумовлюється динамікою доходів населення області.

Інша інтерпретація коефіцієнта детермінації - рівень достовірності рівняння регресії, що формалізує вплив доходів населення області на надходження до зведеного обласного бюджету (без урахування міжбюджетних трансфертів). У нашому випадку цей рівень наближений до 1, тому є високим. Також слід розрахувати коефіцієнт еластичності $(E(x))$ результуючої ознаки за фракторною за фрормулою:

$$
E_{(x)}=a_{1} \frac{\bar{x}}{y(\bar{x})}
$$

де $a_{1}$ - коефіцієнт лінійної регресії, який показує, на скільки одиниць змінюється результуюча ознака при зростанні фракторної ознаки на 1 одиницю;

$\bar{x}$ - середнє значення факторної ознаки;

$y(\bar{x})$ - середнє значення результуючої ознаки. 
Використовуючи фрормулу (1), визначимо коефіцієнт еластичності власних доходів зведених обласних бюджетів України за доходами населення областей:

$$
E_{(x)}=0,081 \cdot \frac{79922,1}{6202,6}=1,044 \% .
$$

Отже, згідно з розрахунком (2), при зростанні доходів населення області на $1 \%$ надходження до зведеного обласного бюджету (без урахування трансфертів) збільшуються на 1,044\%.

Інший фактор, який чинить значний вплив на місцеві фінанси в умовах децентралізації владних повноважень, зважаючи на частку від податку на доходи фрізичних осіб у структурі власних надходжень місцевих бюджетів, - чисельність наявного населення України в регіональному розрізі (табл. 3).

Таблиця 3

\section{Чисельність наявного населення України в регіональному розрізі впродовж 2014-2017 рр., тис. осіб}

\begin{tabular}{|l|c|c|c|c|c|}
\hline \multirow{2}{*}{ Область / обласний центр } & \multicolumn{3}{|c|}{ Значення показника за роками } & \multirow{2}{*}{ Середнє за } \\
\cline { 2 - 5 } & 2014 & 2015 & 2016 & 2017 & $2014-2017$ рр. \\
\hline Вінницька / Вінниця & 1610,6 & 1602,2 & 1590,4 & 1575,8 & 1594,8 \\
\hline Волинська / Луцьк & 1042,9 & 1042,7 & 1041,0 & 1038,5 & 1041,3 \\
\hline Дніпропетровська / Дніпро & 3276,6 & 3254,9 & 3230,4 & 3231,1 & 3248,3 \\
\hline Донецька / Донецьк & 4297,0 & 4265,1 & 4244,0 & 4200,5 & 4251,6 \\
\hline Житомирська / Житомир & 1256,0 & 1247,5 & 1240,5 & 1231,2 & 1243,8 \\
\hline Закарпатська / Ужгород & 1259,6 & 1259,2 & 1258,8 & 1258,2 & 1258,9 \\
\hline Запорізька / Запоріжжя & 1765,9 & 1753,6 & 1739,5 & 1723,2 & 1745,5 \\
\hline Івано-Франківська / Івано-Франківськ & 1382,6 & 1382,3 & 1379,9 & 1377,5 & 1380,6 \\
\hline Київська / Київ & 1729,2 & 1732,2 & 1734,5 & 1754,3 & 1737,5 \\
\hline Кіровоградська / Кропивницький & 980,6 & 973,1 & 965,8 & 956,3 & 968,9 \\
\hline Луганська / Луганськ & 2220,0 & 2205,4 & 2195,3 & 2167,8 & 2197,1 \\
\hline Львівська / Львів & 2537,8 & 2534,2 & 2534,0 & 2529,6 & 2533,9 \\
\hline Миколаївська / Миколаїв & 1164,3 & 1158,2 & 1150,1 & 1141,3 & 1153,5 \\
\hline Одеська / Одеса & 2396,4 & 2390,3 & 2386,5 & 2383,1 & 2389,1 \\
\hline Полтавська / Полтава & 1449,0 & 1438,9 & 1426,8 & 1413,8 & 1432,1 \\
\hline Рівненська / Рівне & 1161,2 & 1161,8 & 1162,7 & 1160,6 & 1161,6 \\
\hline Сумська / Суми & 1123,4 & 1113,3 & 1104,5 & 1094,3 & 1108,9 \\
\hline Тернопільська / Тернопіль & 1069,9 & 1065,7 & 1059,2 & 1052,3 & 1061,8 \\
\hline Харківська / Харків & 2731,3 & 2718,6 & 2701,2 & 2694,0 & 271,3 \\
\hline Херсонська / Херсон & 1067,9 & 1062,4 & 1055,6 & 1047,0 & 1058,2 \\
\hline Хмельницька / Хмельницький & 1301,2 & 1294,4 & 1285,3 & 1274,4 & 1288,8 \\
\hline Черкаська / Черкаси & 1251,8 & 1243,0 & 1231,2 & 1220,4 & 1236,6 \\
\hline Чернівецька / Чернівці & 910,0 & 909,9 & 908,1 & 906,7 & 908,7 \\
\hline Чернігівська / Чернігів & 1055,7 & 1045,0 & 1033,4 & 1020,1 & 1038,5 \\
\hline місто Київ & 2888,0 & 2906,6 & 2925,8 & 2934,5 & 2913,7 \\
\hline
\end{tabular}

Джерело: розроблено та проведено розрахунки за даними Державної служби статистики України [12] без урахування тимчасово окупованої території АРК, м. Севастополя та частини тимчасово окупованих територій у Донецькій та Луганській областях.

За усередненими даними 2014-2017 рр., що наведені у табл. 3, можна зробити висновок, що найбільш населеними регіонами України є місто Київ з 2,9 млн. осіб, Дніпропетровська область з 3,2 млн. осіб та Донецька область з 4,0 млн. осіб. Найменша чисельність наявного населення у Чернігівській (1 млн. 20 тис. осіб), Кіровоградській (956 тис. осіб) і Чернівецькій (907 тис. осіб) областях. У місті Київ і 6 
областях (28\%), наявна чисельність населення в яких за 2014-2017 рр. перевищила 2 млн. осіб, проживає 47,5\% населення України.

Аналізуючи регіональну динаміку демографічного стану України, слід відзначити, що у 2017 р. порівняно з 2014 р. відбулося скорочення чисельності наявного населення на $1,3 \%$, або на 542,5 тис. осіб (без урахування тимчасово окупованої території АРК, м. Севастополя та частини тимчасово окупованих територій у Донецькій та Луганській областях). При цьому приріст наявного населення упродовж 20142017 рр. зафріксовано лише в місті Києві $(+46,5$ тис. осіб, або $+1,6 \%)$ та Київській області $(25,1$ тис. осіб, або $+1,5 \%)$, решта регіонів характеризується скороченням наявного населення від $-0,6$ тис. осіб, або $-0,05 \%$ у Рівненській області до $-52,2$ тис. осіб, або $-2,4 \%$ у Луганській та $-96,5$ тис. осіб, або -2,3\% у Донецькій області.

Зрозуміло, що населення інтенсивніше залишає території, на яких ведуться бойові дії, тому й найбільший від'ємний приріст наявного населення за 2014-2017рр. наявний у Луганській та Донецькій областях.

Проведемо оцінку впливу чисельності наявного населення області на власні доходи зведених обласних бюджетів. Для цього по осі абсцис відкладемо середні значення чисельності наявного населення областей України та міста Києва за 2014-2017 pp., а по осі ординат - середні обсяги власних доходів зведених обласних бюджетів України. В результаті одержуємо графік, що формалізує вплив середньорічної чисельності наявного населення областей на середньорічний обсяг власних доходів зведених обласних бюджетів України за 2014-2017 рр. (рис. 2).

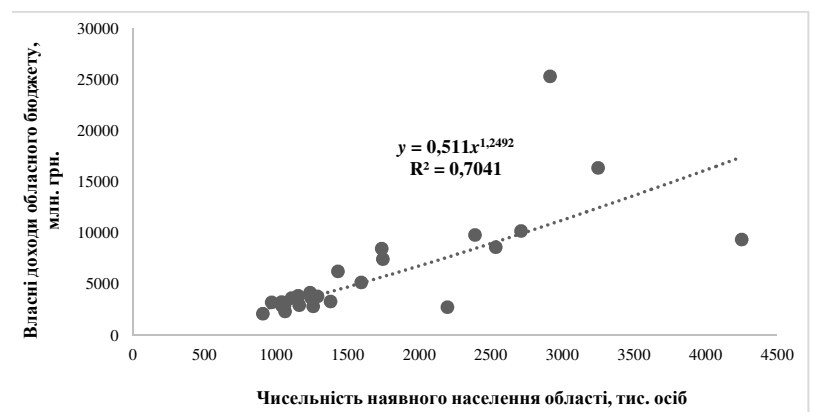

Рис. 2. Формалізація впливу чисельності наявного населення областей на середньорічний обсяг власних доходів зведених обласних бюджетів України за 2014-2017 рp.

Джерело: розроблено та проведено розрахунки за даними Державної казначейської служби України [11] та Державної служби статистики України [12] без урахування тимчасово окупованої території АРК, м. Севастополя та частини тимчасово окупованих територій у Донецькій та Луганській областях.

Оскільки фрормула, наведена на рис. 2, є степеневою функцією, коефріцієнтом еластичності власних доходів зведеного бюджету за чисельністю наявного населення області $€$ степінь біля змінної х, тому можна зробити висновок, що при зростанні чисельності наявного населення області на $1 \%$ власні доходи зведеного обласного 
бюджету можуть збільшитися на 1,25\%. При цьому коефіцієнт парної детермінації $R^{2}=0,704$ означає, що зростання власних доходів зведених обласних бюджетів на $70,4 \%$ обумовлюється динамікою чисельності наявного населення області. Тому рівень достовірності рівняння регресії, що формалізує вплив чисельності наявного населення області на надходження до зведеного обласного бюджету (без урахування міжбюджетних трансфертів) є високим і достатнім для його подальшого використання в аналізі та прогнозуванні.

Висновки і перспективи подальших розвідок. Отже, за результатами проведеного аналізу було встановлено, що, здійснюючи управління власними доходами місцевих бюджетів України в умовах фрінансової децентралізації, слід зважати на ряд важливих чинників. По-перше, упродовж 2014-2017 рр. відбулося зростання загального обсягу власних доходів місцевих бюджетів України в 2,3 рази, при чому третину з них сформовано за рахунок надходжень до зведених обласних бюджетів Одещини, Дніпропетровщини та міста Києва. По-друге, збільшення на $1,04 \%$ обсягу власних доходів адміністративно-територіальних одиниць на 98,2\% обумовлюється зростанням доходів населення на 1\%. По-третє, $з$ достовірністю $70,4 \%$ було встановлено, що обсяг власних доходів зведеного обласного бюджету збільшується на 1,25\% при зростанні чисельності наявного населення області на $1 \%$. Отже, для підвищення ефективності управління власними доходами місцевих бюджетів уряду, крім подальшого розширення фрінансових повноважень громад, потрібно забезпечити сприятливі передумови для зростання добробуту громадян, нівелювання диспропорцій у регіональному розподілі доходів населення і відповідно зниження потоку трудових іммігрантів, що могли стати предметом подальших досліджень.

\section{Література}

1. Kyriacou A. P., Muinelo-Gallo L., Roca-Sagalés O. Fiscal decentralization and regional disparities: The importance of good governance. Papers in Regional Science. 2013. Vol. 94. No. 1. P. 89-108. DOI : https://doi.org/10.1111/pirs.12061.

2. Волохова І. С. Місцеві фрінанси та перспективи поглиблення фінансової децентралізації в Україні : моногр. Одеса : Атлант, 2014. 462 с.

3. Сидор І. Власні і закріплені доходи місцевих бюджетів: проблеми формування та резерви зростання. Вісник ТНЕУ. 2014. № 3. С. 20-29.

4. Baskaran T., Feld L. P., Schnellenbach J. Fiscal federalism, decentralization, and economic growth: a meta-analysis. Economic Inquiry. 2016. Vol. 54. No. 3., P. 1445-1463. DOI : https://doi.org/10.1111/ecin.12331.

5. Возняк Г. Фінансова децентралізація та стале ендогенне зростання регіонів: формалізація напрямів впливу. Світ фрінансів. 2019. № 2(59). С. 49-59.

6. Martynenko V. V. Study of international experience in the implementation of fiscal policy in the context of financial decentralization. International Journal of New Economics, Public Administration and Law. 2018. № 2 (2). P. 15-25. DOI: https:// doi.org/10.31264/2545-093X-2018-2(2)-15-25.

7. Martynenko V. V. Estimation of the efficiency of the tax component of the fiscal policy in Ukraine. Strategic Management: Global Trends and National Peculiarities. 
Collective monograph. Kielce : Publishing House «Baltija Publishing». 2019. P. 76-93.

8. Мартиненко В. В. Макроекономічні фактори модернізації фіскальної політики України. Фінансовий простір. 2019. № 1 (33). С. 147-157.

9. Податковий кодекс України № 2755-VI від 02.12.2010 р. Верховна Рада України. URL: https://zakon.rada.gov.ua/laws/show/2755-17 (дата звернення : 20.08.2019).

10. Бюджетний кодекс України № 2756-VI від 08.07.2010 р. Верховна Рада України. URL: https://zakon.rada.gov.ua/laws/show/2456-17 (дата звернення : 20.08.2019).

11. Офріційний сайт Державної казначейської служби України. URL: https://www. treasury.gov.ua/ua (дата звернення : 20.08.2019).

12. Офріційний сайт Державної служби статистики України. URL : http://www.ukrstat. gov.ua/ (дата звернення : 20.08.2019).

\section{References}

1. Kyriacou, A.P., Muinelo-Gallo, L. \& Roca-Sagalés, O. (2013). Fiscal decentralization and regional disparities: The importance of good governance. Papers in Regional Science, 94(1), 89-108. DOI: https://doi.org/10.1111/pirs.12061

2. Volokhova, I.S. (2014). Mistsevi finansy ta perspektyvy pohlyblennia finansovoi detsentralizatsii $\vee$ Ukraini [Local finance and prospects for deepening financial decentralization in Ukraine]. Atlant, Odesa, Ukraine, 462 p. [in Ukrainian].

3. Sydor, I. (2014). Vlasni i zakripleni dokhody mistsevykh biudzhetiv: problemy formuvannia ta rezervy zrostannia [Own and fixed incomes of local budgets: the problem of the formation and reserves of growth]. Visnyk TNEU, 3, 20-29 [in Ukrainian].

4. Baskaran, T., Feld, L.P. \& Schnellenbach, J. (2016). Fiscal federalism, decentralization, and economic growth: a meta-analysis. Economic Inquiry, 54 (3), 1445-1463. DOI: https://doi.org/10.1111/ecin.12331.

5. Voznyak, H. (2019). Finansova detsentralizatsiia ta stale endohenne zrostannia rehioniv: formalizatsiia napriamiv vplyvu [Financial decentralization and sustainable endogenous growth of regions: formalization of impact directions]. World of Finance, 2(59), 49-59 [in Ukrainian].

6. Martynenko, V.V. (2018). Study of international experience in the implementation of fiscal policy in the context of financial decentralization. International Journal of New Economics, Public Administration and Law, 2(2), 15-25. DOI: https://doi. org/10.31264/2545-093X-2018-2(2)-15-25.

7. Martynenko, V.V. (2019). Estimation of the efficiency of the tax component of the fiscal policy in Ukraine. In: Pawlik, A. (ed.) \& Shaposhnykov, K. (ed.) (2019). Strategic Management: Global Trends and National Peculiarities. Publishing House "Baltija Publishing", Kielce, Poland, p. 76-93.

8. Martynenko, V.V. (2019). Makroekonomichni faktory modernizatsii fiskalnoi polityky Ukrainy [Macroeconomic factors of modernization of the fiscal policy of Ukraine]. Finansovyi prostir. 1 (33), 147-157 [in Ukrainian].

9. Podatkovyi kodeks Ukrainy [Tax Code of Ukraine] (2010). zakon.rada.gov.ua. Retrieved from https://zakon.rada.gov.ua/laws/show/2755-17 [in Ukrainian]. 
10. Biudzhetnyi kodeks Ukrainy [Budget Code of Ukraine] (2010). zakon.rada.gov.ua. Retrieved from https://zakon.rada.gov.ua/laws/show/2456-17 [in Ukrainian].

11. Ofitsiinyi sait Derzhavnoi kaznacheiskoi sluzhby Ukrainy [Official site of the State Treasury Service of Ukraine] (2019). treasury.gov.ua. Retrieved from https://www. treasury.gov.ua/ua [in Ukrainian].

12. Ofitsiinyi sait Derzhavnoi sluzhby statystyky Ukrainy [Official site of the State Statistics Service of Ukraine] (2019). ukrstat.gov.ua. Retrieved from http://www. ukrstat.gov.ua/ [in Ukrainian].

Статтю отримано 1 серпня 2019 р.

Article received August 1, 2019. 